\title{
ДЕМОНОЛОГІЧНІ МОТИВИ ТА ОБРАЗИ В РОМАНІ ВАЛЕРІЯ ШЕВЧУКА ДІМ НА ГОРІ
}

\author{
АГНЕШКА ЛЕВАНДОВСЬКА \\ Університет ім. Адама Міцкевича, Познань — Польща \\ aga_lewandowska@wp.eu \\ DEMONOLOGICZNE MOTYWY I OBRAZY \\ W POWIEŚCI WALERIJA SZEWCZUKA DOM NA WZGÓRZU \\ AGNIESZKA LEWANDOWSKA \\ Uniwersytet imienia Adama Mickiewicza, Poznań — Polska
}

STRESZCZENIE. Niniejszy artykuł poświęcony jest analizie motywów i obrazów demonologicznych w powieści Dom na wzgórzu autorstwa Walerija Szewczuka. Zwrócono uwagę na występujące $\mathrm{w}$ dwu częściach powieści postaci demonologiczne oraz ich wpływ na życie bohaterów. Analiza uwzględnia narodowo-kulturowy aspekt wskazanego zagadnienia.

\section{THE DEMONOLOGICAL MOTIFS AND DEPICTIONS \\ IN THE NOVEL A HOUSE ON A MOUNTAIN BY VALERIY SHEVCHUK}

\author{
AGNIESZKA LEWANDOWSKA \\ Adam Mickiewicz University, Poznan — Poland
}

\begin{abstract}
The article is an attempt to present the analysis of the demonological motifs and depictions in novel A House on a Mountain (Дім на горі) by Valeriy Shevchuk. On the basis of two parts of this book we pay attention to the demonic characters that appear there and their impact on other human characters. This analysis is also based on the national and cultural relation to this updated question.
\end{abstract}

$\mathrm{M}$ айстерне переплетіння фантастичного й реального, яскрава присутність демонологічних мотивів та образів у поєднанні 3 повсякденною дійсністю - головні риси поетики роману Дім на горі (1983) Валерія Шевчука. Сам письменник згадує у своїх Автобіографічних замітках: „На початку 70-х я ще писав фольклорно-фантастичні повісті та оповідання з елементами готизму — це був результат мого попереднього захоплення, тобто поетикою фольклорної прози. Я тоді постановив створити анти-Гоголя, бо в Гоголі, як, до речі, і в Довженку, мене вельми дратував їхній «малорусизм» - та естетика, яка подавала українську ментальність через екзотику, не без насмішки (з гумором); мене ж фольклорна народна проза зацікавила з іншого боку, я б сказав, психологічного, бо фантастику і демонологію, ба й готизм я розглядав як стан душі, образний його відбиток”.

Свого часу авторитетний учений Іван Огієнко (митрополит Іларіон) справедливо наголошував: „Поза своїм настирливим і необхідним фізичним життям людина знає необхідне й духове життя, і живе ним ще з свого народження"2.

${ }^{1}$ В. Шевчук, Сад житейський думок, трудів та почуттів. Автобіографічні замітки, Київ 2003, с. 398.

2 Див.: Митрополит І Іларіон, Дохристиянські вірування украӥнського народу, Вінніпег 1965 , с. 5. 
Відповідно до сказаного, людині треба було зрозуміти довкілля, вона помічала не тільки те, що можна було збагнути розумом, але звертала увагу і на явища, незрозумілі й сильніші від неї. Ці надзвичайні дива персоніфікувалися, люди приносили їм жертви, шанували своїх богів, що знаходилися в різних місцях: у горах, лісах, над річкою, потоком, і т. д. ${ }^{3}$. Можемо констатувати, що це було початком демонології в слов'янських країнах, зокрема в Україні.

Слово “демонологія" походить 3 грецької мови й означає "сукупність божеств (злих духів, демонів)' та 'учення про них'. У сучасному релігієзнавстві демонологія - це сукупність вірувань в існування "нечистої сили” і персоніфікація ії істот ${ }^{4}$.

Що стосується слов'янської демонології, то Іван Огієнко підкреслював, що первісно духи були добрими, але із часом почали з'являтись злі демони, яким приписували все лихо на світі.

Коли на українських землях виникло християнство, демонологія була повністю розвинута. Зміни, що тоді відбулися, полягали у виникненні нових слівпонять, зокрема таких, як напр., диявол, демон, сатана та ін. ${ }^{5}$ У християнстві демонологію сприймали як сукупність нечистої сили, усяку погань, натомість божків називали бісами.

Початково людина сповідувала многобожжя, кожному з богів поклонялась. В українському пандемоніумі декілька видів демонів, зокрема родинного вогнища, природи, людських примх та примар і т. п. Поміж найхарактерніших із них виділяємо домовиків, водяників, лісовиків, перелесників, русалок, вїв, чортів, відьом, які рясно заселяють українську демонологію і не в останню чергу твори Валерія Шевчука.

Для прикладу коротко охарактеризуємо деякі з них. Так, у пантеоні духів родинного вогнища - домовик. Він захисник сім'ї, що живе в запічку. Характерна риса домовика - допомагати своїм і шкодити чужим. Однак, родині треба задобрити божка й пам'ятати про нього, щоб він не нашкодив і своїм ${ }^{6}$.

Богів природи ілюструють, напр., водяники, лісовики, перелесники, русалки, вї та ін. Водяник - „водяний цар, що володіє всією водою в світі: ріками, озерами, болотами, морями, та ін.”․ Водяники - „старі, волохаті діди з довжелезною кудлатою бородою, що можуть сильно шкодити людині, коли вона непрошено вривається до їхнього царства"в.

Господарями лісів є лісовики (полісуни). Вони мешкають на густих деревах, або по дуплах сухих дерев. Лісовик такий високий, як дерево або й вище. Цей божок лякає людину, коли дико верещить та стогне. Лісовикам підпорядковані всі тварини ${ }^{9}$.

Перелесник - спокусник, що заманює гарних дівчат та призводить їх до смерті. Це “найзліший повітряний дух" ${ }^{10}$. Він відвідує людей, набираючи вигляду близької, коханої людини. Леся Українка в Лісовій пісні (1911) так описала

${ }^{3}$ Там само, с. 120.

4 Див., напр.: Универсальная научно-популярная онлайн-энщиклопедия, [в:] Електронний pecypc: http://www.krugosvet.ru/enc/kultura_i_obrazovanie/religiya/DEMONOLOGIYA.html (28.12.2016); В. Войтович, Українська міфологія, Київ 2002, с. 129.

${ }^{5}$ Митрополит Іл аріон, Дохристиянські вірування украӥнського народу..., с. 123.

${ }^{6}$ Там само, с. 124.

${ }^{7}$ Там само, с. 128.

${ }^{8}$ Там само.

${ }^{9}$ Там само, с. 129.

${ }^{10}$ В. В о й то в ич, Украйнська міфологія..., с. 361. 
цього божка: „Перелесник - гарний хлопець у червоній одежі, з червонястим, буйно розвіяним як вітер волоссям, 3 чорними бровами, з блискучими очима" ${ }^{11}$.

У водах, крім водяників, живуть також богині - русалки. Вони „неназвані маленькі дівчатка, мертвонароджені чи приспані матерями. Русалки дуже гарні 3 лиця, тіло в них блакитне чи синє, зелені або чорні очі та довгі пухнасті віі”"12. Виходять вони на Трійцю, живуть у лісах або на полях. Узимку водяні королеви входять у землю, там не відчувають холоду. Русалки проводять час весело ${ }^{13}$.

Найсильнішим та чи не найжахливішим представником нечистої сили $€$ вiй ${ }^{14}$. Ця істота живе під землею. Він одинокий, керує чортами. Кажуть, що в його оці живе сам сатана. Образ вія зображений, напр., в однойменній повісті Миколи Гоголя.

Найпоширенішим жіночим персонажем слов'янської демонології є вiдbмa. Вона характеризується як зловісна, гидка баба з гачкуватим носом та хвостом ${ }^{15}$. Bidbмa знає чарівні властивості рослин, тварин, речовин, може мати різний вигляд, пересуватися в просторі ${ }^{16}$.

Іншою фантастичною істотою, яка має багато номінацій, є чорт. Його називають ще сатана, біс, змій, диявол, дябел, чорний, проклятий, нечиста сила, демон та ін. ${ }^{17}$ Чорт - це персоніфікація всієї нечистої сили в одній особі. Він завжди підказує людині недобрі думки. Чорт звіровидний, любить перекидатися в чорного пса, кота чи свиню. „Звичайно чорт невидимий, а коли з'являється, то він чорний, волохатий і з хвостом, а очі в нього як жарини; ноги звичайно цапині, собачі або курячі [...]. Чорт завжди шукає собі людей, щоб за ласощі цьогосвітні продали йому душу [...]. Звичайно чорт має крила і літає. Має він на собі і роги, але роги тут ознака його великої сили"18.

Згадуваний вище Іван Огієнко підкреслював, що, по суті, усі українські письменники, частіше чи рідше, звертались у своїй творчості до мотиву нечистої сили, зокрема Іван Котляревський, Григорій Квітка-Основ'яненко, Тарас Шевченко, Марко Вовчок, Панас Мирний, Леся Українка, Іван Нечуй-Левицький, Борис Грінченко. Останній описав, напр., в оповіданні Під тихими вербами (1901) кілька прикладів нечистої сили: А в лісі живе полісун. Ходить з великою пугою і ганяє вовків, бо він вовчий бог. Де війна, то він туди й турить ӥх на прокорм... Такий, як чоловік, тільки великий, як дерево... I від його тіні немає; усе має тінь, а він - ні... А в полі живе польовий - і то нечиста сила... А в очереті над річкою очеретяник - вибігає з очерету білим бараном і лякає людей... А в воді живе водяний - ией у зелений кушир уплутаний, пакості чинить, греблі рве... А в болоті живе болотяник - такий замурзаний та вкаляний... Уночі затягає в болото чоловіка... вогником світить серед болота, а чоловік думає, щз там люди, іде туди, а воно все далі, далі... аж поки заведе в таку ковбаню, щоо й загрузне бідолашний чоловік... А в скелі живе змій. I ие нечиста сила ${ }^{19}$. До

${ }^{11}$ Митрополи т Іларі он, Дохристиянські вірування украӥнського народу..., с. 129.

${ }^{12}$ В. Войто в и ч, Украӥнська міфологія..., с. 449.

${ }^{13}$ Митрополит Іларі он, Дохристиянські вірування украӥнського народу..., с. 130.

${ }^{14}$ В. В ой то в ич, Украӥнська міфологія ..., с. 72.

${ }^{15}$ В. Милорадович, Українська відьма. Нариси з української демонології, Веселка 1993, с. 48.

16 Див.: Ю. Г. Писаренко, Відьма, [в:] Електронний ресурс: Енщиклопедія історії України, http://resource.history.org.ua/cgi-bin/eiu/history.exe?\&I21DBN=EIU\&P21DBN=EIU\&S21S $\mathrm{TN}=1 \& \mathrm{~S} 21 \mathrm{REF}=10 \& \mathrm{~S} 21 \mathrm{FMT}=$ eiu all $\& \mathrm{C} 21 \mathrm{COM}=\mathrm{S} \& \mathrm{~S} 21 \mathrm{CNR}=20 \& \mathrm{~S} 21 \mathrm{P} 01=0 \& \mathrm{~S} 21 \mathrm{P} 02=0 \& \mathrm{~S} 21 \mathrm{P} 0$ $3=\mathrm{TRN}=\& \mathrm{~S} 21 \mathrm{COLORTERMS}=0 \& \overline{\mathrm{S}} 21 \mathrm{STR}=\operatorname{Vidma}(28.12 .2016)$.

${ }^{17}$ В. Милорадович, Украӥнська відьма ..., с. 26.

${ }^{18}$ Митр ополит І І арі он, Дохристиянські вірування украйнського народу..., с. 142.

${ }^{19}$ Там само, с. $148-149$. 
вказаного вище списку письменників, що цікавились демонологічними мотивами можемо додати й таких авторів, як: Бенедикт Хмелевський, Іоаникій Галятовський, Самійло Величко, Стефан Яворський, Петро Могила, Дмитро Туптало, Стефан Яворський, Олекса Стороженко, Наталена Королева, Олексій Плющ, Юрій Липа, Ростислав Єндик, Марія Голод, Юрій Андрухович, Володимир Єшкілєв та ін. ${ }^{20}$

Демонологічні мотиви та образи характерні й для готичної літератури, традиція якої надзвичайно багата в українському письменстві від його початків аж до сучасності ${ }^{21}$, про що писав зокрема й сам автор Дому на горі.

Валерій Шевчук народився в родині шевця 20 серпня 1939 року в Житомирі. Літературою він зацікавився в дитинстві (тут велику роль відіграли його мати та брат, які почали формувати ставлення майбутнього письменника до літератури). Перші вірші В. Шевчука не були успішними. Почав їх писати в четвертому класі і - як сам стверджував - не було в них ні ритму, ні образів ${ }^{22}$. У десятому класі він пробував писати прозу: оповідання, історичні романи і т. п.

Українську літературу В. Шевчук почав вивчати та розуміти під впливом творчості та методології Івана Франка та Григорія Сковороди. Останній став для письменника своєрідним учителем життя, духовним батьком. У прозі письменник дебютував оповіданням Настунька про Тараса Шевченка. Сам В. Шевчук уважає, що вершиною його ранньої новелістичної творчості був рік 1962. Тоді активно друкувався - шістдесяті роки були найбільш плодотворним періодом у його житті. У 1963 році він закінчив історико-філософський факультет Київського університету імені Тараса Шевченка.

Сімдесяті роки виявилися важкими для письменника, тому що його практично не друкували. В. Шевчук попав у “чорний список”. Натомість кращими роками стали для нього вісімдесяті (на думку В. Шевчука, це його "золотий час"23). Саме на ті роки припадає пора посиленої творчої активності письменника, коли він мав змогу художньо реалізувати себе.

Літературна спадщина В. Шевчука багата. Він автор таких книжок, як: $\mathrm{Ce}$ ред тижня (1967), Набережна 12 (1968), Середохрестя (1966), Вечір святої осені (1969), Крик півня на світанку (1979), Долина джерел (1981), Тепла осінь (1981), На полі смиренному (1982), Дім на горі (1983), Маленьке вечірнє інтермецио (1984), Барви осіннього саду (1986), Три листки за вікном (1986, за яку в 1988 року отримав Державну премію ім. Тараса Шевченка), Камінна луна (1987), Птахи з невидимого острова (1989), Дзитар одвічний (1990), Дорога в тисячу років (1990) $)^{24}$, Жінка змія (1998), Юнаки з вогненної печі (1999), Біг плоті (1999), Срібне молоко (2002). Тіні зникомі. Сімейна хроніка (2002), Темна музика сосон (2003), Компанія з пивнищі біля Чуднівського мосту (2006) та ін ${ }^{25}$.

20 Демонологічні мотиви, наявні у творах указаних вище авторів зібрані, між іншим, в наступних антологіях: Антологія українського жаху, упоряд. В. Пахаренко, Київ 2000, 800 с.; Ю. Винничук, Чорт зна щзо, Львів 2004, 792 с. та ін.

${ }^{21}$ Валерій Шевчук зазначав, що українська готична проза добре вписується в європейський і світовий контексти і при цьому наділена неповторним жанрово-тематичним й стильовим колоритом. Див., напр. В. Шевчук, 3 темних джерел життя. Українська готична новела ХХ століття, [в:] „Літературна Україна” 1995, № 4, 5, 6.

${ }_{22}$ В. Ше вчук, Сад житейський думок, трудів та почуттів..., с. 344.

${ }^{23}$ Там само, с. 404.

${ }^{24}$ Див.: Живиия. Хрестоматія украӥнської літератури ХХ століття, упоряд. М. М. Кон он чук, Н. I.Бондар, Т. І.Конончук, Київ 1998, с. 581.

${ }_{25}$ Біографія Валерія Шевчука, [в:] Електронний ресурс: https://onlyart.org.ua/biographiespoets-and-writers/shevchuk-valerij-biografiya/ (28.12.2016). 
Роман-баладу Дім на горi Валерій Шевчук писав протягом 1966-1980 років, опублікувавши в 1983 році. Твір, на долю якого випало стати чи не найбільш розпізнавальним поміж прозової спадщини письменника, дочекався багатьох наукових розвідок та досліджень. Свої думки з приводу унікальності Шевчукової прози висловлювали, зокрема й такі українські літературознавці, як Людмила Тарнашинська, Микола Ільницький, Марко Павлишин, Микола Жулинський, Анна Горнятко-Шумилович, Роман Корогодський, Андрій Кравченко, Володимир Панченко, Агнєшка Пивоварська, Анна Берегуляк, Тетяна Блєдних, Ольга Карпова, Марина Франчук, Ганна Файзулліна, Наталія Кобилко, Галина Грибан та ін. ${ }^{26}$

Вищевказані дослідники розглядали творчість В. Шевчука в різних ракурcax. Характеризуючи проблематику Шевчукових творів, учені наголошували на таких аспектах його прозової спадщини, як звернення до джерел "концепції щастя” Григорія Сковороди, західної філософії екзистенціалізму, відображення життя “людини серед людей”, яка, за влучним визначенням письменника, „соціально на нулю, зате багата внутрішньо”. У сфері поетики творів В. Шевчука увагу дослідників привертали такі поетичні атрибути його творчості, як умовність, бароковість, “химерність”, трансформація фольклорних джерел, мотивів та образів.

Уважаємо за доцільне звернути увагу на деякі аспекти вказаних вище досліджень, що торкаються предмету нашого аналізу.

Так, Ольга Карпова, аналізуючи прозу письменника-шістдесятника, указує на барокові риси його прози, зокрема контрастність, антиномічність, антите-

${ }_{26}^{26}$ Див., напр.: Л. Тарнашинська, Закон піраміди, або чи існує форма ідеального „, ,, [в:] „Дніпро” 1990, № 12, с. 134-136; Л. Тарнаш инська, „Ліпше бути ніким, ніж рабом”, [в:] „Дніпро” 1991, № 10, с. 69-79; Н.Н.Ильн и ц и й, Схожесть несхожего, [в:] „Вопросы литературы” 1980, № 11, с. 36-37; М. Павлиш и н, ,Дім на горі” Валерія Шевчука, [в:] „Сучасність” 1987, № 11, с. 28-40; М. Пав лишин, Канон та іконостас: Літературно-критичні cmammi, Київ 1997, 445 с.; М.Жули н ський, До людини і світу - з любов'ю, [в:] В . Шевч у к, Дім на горі, [в:] Й о го ж, Вибрані твори: Роман-балада. Оповідання, передм. М. Жул и н с ько го, Київ 1989, с. 5-15; М. Жул и н с ь к и й, ,...І метафори реального життя”, [в:] Й о го ж, Наближення. Літературні діалоги, Київ 1986, с. 224-253; М. Жулинський , „...I сповіщає нам голос трави”, [в:] В. Шевчук, Дім на горі, Київ 1983, с. 468-486; А. Горн я ткоШу м и ло в ич, Проза Валерія Шевчука: традииійне і новаторське, Щецин 2001, 168 с.; Р. Ко рогодський, Біля вічної ріки, або в пошуках внутрішньої людини, [в:] „Дзвін” 1996, № 3, с. 135-154; А. С. Кра вчен ко, Художня умовність в украӥнській радянській прозі, Київ 1988; В. Панче н ко, Маленькі свята серед буднів, [в:] „Вітчизна” 1988, № 2, с. 180-183; А . Пи в ов арська, Дім на горі. Розмова з Валерісм Шевчуком, пер. $з$ польської Н. Білоцерків ець, [в:] „Сучасність” 1992, № 3, с. 54-59; А.Бер егул як, Магічний реалізм та літературний міф - зиілення чи панацея у постколоніальному контексті?, пер. 3 англ. М. Прокопов ич. [в:] „Сучасність” 1993, № 3, с. 67-75; Т. Блє дн их, Історія в прозі Валерія Шевчука, [в:] „Слово і час" 1993, № 4, с. 52-57; О. Карпова, Демонологічний дискурс прози Валерія Шевчука, автореф. дис. ... канд. філол. наук, Херсон 2008, [в:] Електронний ресурс: www.0zd.ru/literatura/ demonologichnij_diskurs_prozi_valeriya.html (28.12.2016); М. Фран чук, Демонологія у романі Валерія Шевчука “Дім на горі” як жанротворчий засіб, [в:] Електронний ресурс: http://irbis-nbuv. gov.ua/cg-bin/irbis_nbuv/cgiirbis_64.exe?C21COM=2\&I21DBN=UJRN\&P21DBN=UJRN\&IMAGE_

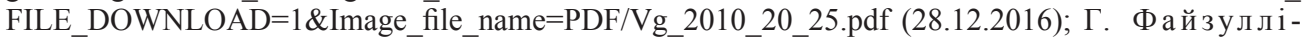
н а, Міфопоезис української етнокультури у філософськомуу романі Валерія Шевчука "Дім на горі”, [в:] Електронний ресурс: http://irbis-nbuv.gov.ua/cgi-bin/irbis_nbuv/cgiirbis_64.exe?C21CO$\mathrm{M}=2 \& \mathrm{I} 21 \mathrm{DBN}=\mathrm{UJRN} \& \mathrm{P} 21 \mathrm{DBN}=\mathrm{UJRN} \& \mathrm{IMAGE}$ FILE_DOWNLOAD $=1 \&$ Image_file_name $=\mathrm{PDF} /$ apitphk_2013_31_51.pdf, с. 7 (28.12.2016); Н. Коб и л ко, Реальний і міфологічний хронотоп дороги в романі Валерія Шевчука „Дім на горі”, [в:] „Наук. зап. ХНПУ ім. Г. С. Сковороди. Сер. Літературознавство”, зб. наук. праць, Харків 2014, вип. 2 (78), 2 ч., с. 74-81; Г. Гр и бан, Демонологічна образність роману-балади Валерія Шевчука „Дім на горі”, [в:] „Істор.-філол. зб. регіон. проблем”, зб. наук. праць, Житомир 2010, № 20 та ін. 
тичність і синкретичність, завдяки яким герої бачать світ і себе в ньому, натомість автор розбудовує художній часопростір тексту та інтерпретує його; динамізм, експресивність, полісемантизм, символічність, орієнтацію на читачаінтелектуала, інтертекстуальність тексту та ін. ${ }^{27}$.

Характеризуючи демонологічні вкраплення в тканину Шевчукового твору, Марина Франчук зауважує, що в сучасній українській літературі досить помітні форми легенд, казок чи міфів. Континуація фольклорних та фантастичних мотивів впливає на сприймання культури та ментальності. На думку зазначеної авторки, „ця проза відзначається особливою прихильністю письменників до різних форм умовності, казкових ситуацій, химерним сплетінням фантастичного й реального, алегоричним наповненням образів, вільним поводженням з просторовими й часовими координатами, стилістичною поліфонією"28.

Творчість Валерія Шевчука глибоко аналізує діаспорний критик Марко Павлишин. У праці Канон та іконостас (1997) він характеризує прозу письменника, зокрема і його Дім на горі. Цей дослідник уважає зазначений роман складним, багатовимірним, повним значень. Водночас учений наголошує на вмінні В. Шевчука тримати читачів у напруженні й зацікавленні ${ }^{29}$. М. Павлишин звертає увагу на термін "роман-балада". Головним мотивом такого роману $є$ кохання. Однак Дім на горі показує нетипове кохання між жінкою і демонічним створінням. Це кохання інше - символічне, магічне ${ }^{30}$. На думку М. Павлишина, письменник-шістдесятник виражає свої погляди на тему української культури й літератури. Він показує це насамперед крізь призму традиції “химерного” роману, що вважається українським феноменом, який спирається на національну культуру.

Анна Горнятко-Шумилович звертає увагу на напівфантастичну ситуацію повісті-преамбули та міф “дому на горі”, що виходить з реальних рамок: „Долі героїв - Володимира, Івана Шевчука, Галі, Марії Яківни, Хлопця, навіть джигуна Анатоля - заземлені в конкретні ситуації історичної дійсності [...], здобувають реальні людські риси"з1. Дослідниця наголошує, що переплетіння фантастичного та реального світів віддзеркалені як у першій, так і в другій частинах роману.

Галина Грибан уважає В. Шевчука одним 3 „найцікавіших письменників сучасності” 32 , новатором, філософом, який черпає знання 3 українського фольклору та міфології. Учена пише про вплив естетики бароко на аналізований роман. Прикметно, що у творі помітні два сюжетні мотиви - мотив дому, із якого герой виходить і до якого згодом повертається, та мотив дороги, що постійно манить героя. Названа авторка вважає найбільшим досягненням В. Шевчука - прагнення проникнути в давні уявлення народу, вивчити тодішню культуру, осмислити фольклорні образи та наповнити їх сучасним змістом ${ }^{33}$.

Наведені вище слова критиків підтверджують, що демонологія, активне звернення до фольклору в сучасній українській літературі, зокрема і у творчості В. Шевчука, помітно впливають на сучасну культуру та світосприйняття українського народу.

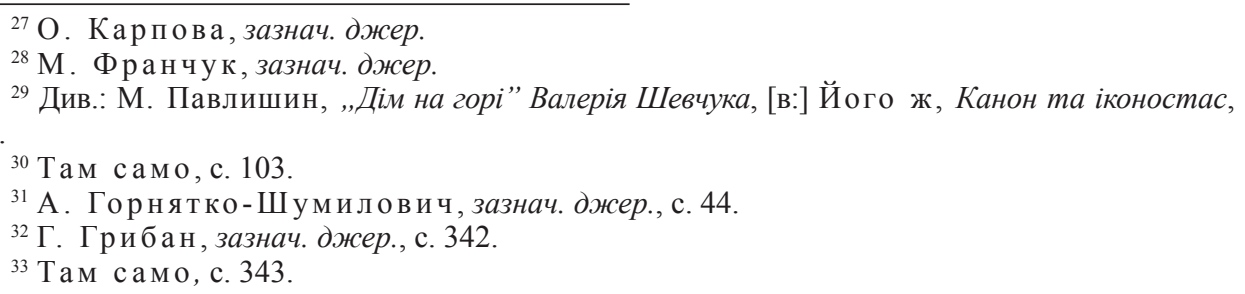


Прикметно, що в Шевчуковому творі вміло поєднані традиційна тематика, заглиблена в українську демонологію, з новаторською поетикою, властивою зразкам українського “химерного" роману, що став феноменом 70-х і 80-х років XX ст. і водночас своєрідним відповідником латиноамериканського "магічного реалізму" ${ }^{\prime 4}$.

Аналізований твір складається з двох частин: повісті-преамбули, що отримала заголовну назву Дім на горi, та циклу тринадцяти ${ }^{35}$ оповідань Голос трави. Обидві частини об’єднує спільний герой - козопас за фахом і філософ від природи, своєрідне alter ego письменника - Іван Шевчук. У творі існують два виміри життя героїв - реальний та фантастичний. Вони співіснують: люди та представники магічного світу паруються ${ }^{36}$. Тут виразно формується домінанта В. Шевчука - він не позбавляє цих образів ні фольклору, ні міфології, магії, хоча його тексти й написані в сучасному стилі, сповнені таємничості, символічні.

Повість-преамбула містить шість розділів, із поміж яких чи не наймагічніший третій, де розгорнуто таємницю заголовного “дому на горі”. Дім має свою легенду, суть якої розкриває перед онукою Галею одна із жіночих героїнь - бабуся: „Наш дім трохи незвичайний, ласочко, — сказала бабця після паузи. Може, вже пора тобі про це розказати... Так от, народжуються в цьому домі здебільшого дівчата, чоловіки сюди приходять... Вони підіймаються знизу і, як правило, просять напитися води. Той, хто нап’ється з наших рук, переступає цей поріг і залишається в домі назавжди. Так було в моєї бабуні, моєї матері і в мене. Так було і в матері твоєї, так повинно статись і з тобою... Мені бракує розуму, щоб все це пояснити, але так воно траплялося... [...]. - Приходять до нас і інші чоловіки. Принаймні до мене і до моєї бабці. До твоєї матері і до матері моєї. Ці пришельці не підіймаються знизу і не просять напитися води, вони з'являються бозна-звідки...”" які згодом покидають дім і вирушають у дорогу. Розказана старою героїнею легенда передається 3 покоління в покоління всім молодим дівчатам, які живуть у домі. Галя ставиться до неї як до казки, вигаданої бабусею. У легенді важливу роль відіграє таємничий мужчина — напівлюдина-напівптах: „,...] біля будинку на горі з'явився джигун у лакованих туфлях, сірому костюмі і в легкому солом'яному капелюсі. Звідкіля він узявся, не помітив ніхто; знизу, однак, не підіймався він напевне. [...] Відтак створилось у Галі враження, що джигун спустився до них на гору на крилах — костюм у нього був бездоганно напрасований, а туфлі сяяли, начебто ходив він не по пилястій жорстві, а по асфальту. Джигун приходив посидіти на скелі, часом він проходжувався по кам'янистих стежках, і Галя не могла на нього не дивитися" ${ }^{38}$. Напівлюдина-напівптах називає себе Анатолем. У нього звабливий зір і магічна міць. Він представник демонічної сили. Це відомий з українського фольклору різновид перелесника, що спокушує молодих дівчат, відвідує їх доти, доки не досягне своєї мети - здійснить статевий акт. Усе відбувається в супроводі місячної ночі. Сам місяць стає тут сим-

\footnotetext{
${ }^{34}$ На цю тему детально див.: А. Горнятко-Шумилович, Проза Валерія Шевчука: традииійне і новаторське...

${ }^{35}$ Це число магутності, магії, воно невипадкове, божественне. Див.: Число могущества тринадцать, [в:] Електронний ресурс: http://soznanie.info/st_chislo_13.html (28.12.2016).

${ }^{36}$ Там само.

${ }^{37}$ В. Шевчук, Дім на горі, [в:] Його ж, Вибр. твори: Роман-балада. Оповідання, передм. М. Жулинського, Київ 1989, с. 80-81.

${ }^{38}$ Там само, с. 77.
} 
волом таємничих, невпізнанних та незрозумілих сил, символом зла та магії ${ }^{39}$. В. Шевчук використовує прийом “двійництва" світ співіснують один з одним, впливають один на одного. На межі двох світів балансують Іван Шевчук та Хлопець. Вони живуть у звичайних сім'ях, здавалось би, їхнє життя іде своїм звичайним ходом. Однак це виняткові герої. Вони бачать більше, ніж пересічні люди. Іван Шевчук володіє здатністю ясновидіння, уміє розмовляти 3 довкіллям, відчуває різні моменти, що відбуваються в сім'ї. Як Іван Шевчук, так і Хлопець на певному етапі життя обирають мандри, вирушають у дорогу. Така їхня доля і життєве покликання. Пошук життєвої дороги стає для них пошуком життєвої істини, забезпечує відчуття свободи й можливість самостійно вирішувати свою долю. Іван Шевчук стає козопасом. Симптоматично, що коза - це символ свободи, але також чарів ${ }^{41}$. Мотив дороги наявний і в другій частині Шевчукового роману - Голос трави. У першій з новелДорога — головний герой — це домовик, роль якого захищати сім'ю. Він не виконує своєї ролі, що стає причиною самогубства господаря. Душевна роздвоєність домовика не дає змоги йому зосередитись на головному завданні - захисті дому. Домовик шукає свій шлях, мандрує ніччю (таємничий час, те, що ірраціональне, несвідоме). Його манить свобода, він закохується у відьму. Життя в запічку не цікавить його. А все ж таки місце домовика вдома, він повертається туди, щоб з тугою споглядати плин життя крізь вікно: „Після тієї пам’ятної ночі домовик уже не покидав маєтку. Вилазив на горище і снував по завитих павутиною кутках. Інколи підходив до вікна, але знову повертався. Йому було самотньо й тужно"42. В аналізованому вище оповіданні В. Шевчук показує співіснування реального та фантастичного світів, синкретичний спосіб мислення, непереможну віру в силу магії.

Цікавим з погляду використання письменником демонологічних мотивів та образів є новела Швець, що віддзеркалює двобій між добром і злом. У творі з'являється постать лісника-диявола, який хоче, щоб швець підписав договір. Швець продає душу, отримує гроші. Знає, що диявол прийде по нього, захоче його душу. Диявол приходить тричі (символ Святої Трійці), але швець кожного разу тікає від смерті. Остання зустріч символічна. Це перемога добра над злом. Швець помирає, але водночас рятує всіх людей, душі яких забрав диявол. Йому допомогла чиста душа.

Образ відьми з однойменної новели циклу Голос трави - амбівалентний. Відьма може заподіювати лихо, але може й чинити добро. Тут розгорнутий образ Меланки - дівчини, яка відчуває, що вона відьма. У маєтку князя Долинського вона наслідує відьму, але в неї немає сили. Усе змінюється після згвалтування дівчини Долинським, коли Меланка хоче відомстити кривднику: „[...] вона повірила в те, у що досі не вірила сама і в що ніяк не хотів вірити князь: ставала серед цієї ночі відьмою, належала цій темені і належатиме їй завжди"43. Усі нещастя, що відбувалися в маєтку, дівчина приписала собі.

Інший образ нечистої сили представлений у Чорній кумі. Відьма допомагає Іванові, який хоче охрестити дитину. На хрестинах весело, магічно - пе-

\footnotetext{
${ }^{39}$ Див.: W. Kopaliński, Stownik symboli, Warszawa 1990, s. 179.

${ }^{40}$ На прийом “двійництва” вказує також Ганна Файзулліна. Дослідниця звертає увагу на образ двійника Галі - “блакитну богиню”. Див.: Г. Фа йзулл лін а, Miфопоезис української етнокультури у філософському романі Валерія Шевчука „Дім на горі”..., с. 7.

${ }^{41}$ W. Kopaliński, Stownik symboli..., s. 166.

${ }^{42}$ В. Шевчук, Дім на горі ..., с. 240.

${ }^{43}$ Там само, с. 274.
} 
сик, який раніше вмів говорити, стає “чоловіченям", кобза сама грає. Водночас це не остання зустріч Івана 3 відьмою. Саме вона допомагає чоловіку стати “великим лікарем". Герої зустрічаються, щоб допомогти хворим односельчанам. У цій новелі образ відьми позитивний, хоча, за словами героїні, „нема нічого у світі тільки лихого чи тільки доброго, [...]. I хто зна, чи таке вже щастя дасть тобі моє добро" 44 .

Наголосимо, що тринадцять оповідань Голосу трави має алегоричну форму. Їхня фольклорно-міфологічна основа — “багаторазове збільшувальне скло”, крізь яке читач побачить споконвічні людські дилеми, що спроектовані знову на сучасність. Як зазначають дослідники, кожне оповідання - це притча, морально-етичний постулат: „душевна роздвоєність може призвести до загибелі (Панна сотниківна), у людській психіці існує безпідставне зло, що породжує ненависть, заздрість, бажання помсти (Джума, Відьма, Сиві хмари), справжня любов не може живитися облудою (Перелесник), за скоєне зло обов'язково настане розплата (Самсон) та ін." ${ }^{45}$ Вищевказані постулати реалізуються за допомогою уведених у тканину оповідань демонологічних постатей, зокрема таких, як домовик (Дорога), чорт (Швець), відьма (Панна сотниківна; Відьма, Чорна кума), перелесник (Перелесник), чаклунка (Голос трави) та ін.

Дім на горі - це квінтесенція українського фольклору, що відроджується в сучасній літературі. Сам письменник сприймав демонологічні образи та мотиви як голос із давнини, у якому звучать споконвічні морально-етичні настанови, розглядав їх, за його влучним висловом, “як стан душі”. Шевчукова любов і глибока пошана до фольклорної спадщини має неоціненне значення для культури українського народу, у той же час і літератури в їі реально-магічному різновиді.

\footnotetext{
${ }^{44}$ Там само, с. 392.

45 Див.: А. Горн ятко-Шуми лов ич, Проза Валерія Шевчука: традииійне $і$ новаторське, Щецин 2001, с. 44.
} 